\title{
The Principle Contradictions in the New Era and the Mission and Responsibility of the Contemporary Youth
}

\author{
Zhang Qinxia, Zheng Rong \\ Marxism College of Xi'an International Studies University, Xi'an, Shaanxi, 710128, China
}

Keywords: new era; principle social contradiction; new change; youth; mission; responsibility

\begin{abstract}
With the entry of socialism with Chinese characteristics into the new era, the main contradiction of our society has been transformed into the contradiction between the growing demand for better life of the people and the unbalanced and insufficient development. The most fundamental way to solve the main contradiction is to rely on development and innovation, thus $\mathrm{Xi}$ Jinping as the general secretary of the CPC Central Committee put forward five development concept of "innovation, harmony, green, open and sharing". The youth are the future and hope of the country, the fate of the youth and the prosperity of the country are closely related. The youth should establish ideal and belief consistent with the era theme, plan their own life and future based on changes of the main social contradiction and the five development concept, shoulder the mission to serve the society, contribute to the country, and mind the world, highlight the ambition and responsibility, fly life dream in the enthusiastic youth, and accomplish career in the struggling youth.
\end{abstract}

\section{Introduction}

General Secretary Xi Jinping pointed out in the report of the 19th National Congress of the CPC that "The socialism with Chinese characteristics has entered the new era, and the major social contradiction in our country has been transformed into a contradiction between the people's ever-growing needs for a better life and unbalanced and insufficient development." ${ }^{\text {,1] }}$ General Secretary Xi Jinping also proposed the major strategic proposition of "To cultivate people in the new era of undertaking the responsibility for national rejuvenation.” The understanding of the mission and responsibility of the younger generation in the new era is a new research topic proposed by the Party Central Committee, which is directly related to China's future and the realization of the two centenary goals. Mao Zedong pointed out in his On Contradiction that "In the development course of complex matters, there are many contradictions, of which there must be one major contradiction, because of its existence and development regulates and influences the existence and development of other contradictions". [2](p320) The main contradiction "plays a leading and decisive role in social development." Due to the status and role of major contradiction, it is necessary for us to make every effort to find out the main contradiction of matters in the development of real life, grasp the major contradiction, and seize the key of the problem.

The major contradiction in the new era means that policies of Chinese social development in the future will change correspondingly. For the younger generation, new changes in new era bring fairer competition environment and more habitable modern ecological environment and more opportunities and platforms for the development. At the same time, for them, major contradiction in new era also means more responsibilities and mission. Xi Jinping points out that "The future of the younger generation is the future of China and Chinese nation. The youth is the important embodiment of the vitality of a country's development and an important factor in a country's core competitiveness." ${ }^{[3]}$ The value orientation of the young people determines the value orientation of the whole society and the realization of common ideal of the Chinese people of all nationalities. The youth undertake the responsibility and mission in the new era, and the Chinese dream of great rejuvenation of the Chinese nation will come true. 


\section{Changes of people's needs and responsibility and mission of contemporary youth}

In the new era, the people's needs have undergone major changes compared with that in the past. In the early era of reform and opening-up, people wanted to be rich, being fed, and it was urgent to solve the subsistence problem. With the further development of social life and people's basic survival problems solved basically, the demand for spiritual life, social development, public affairs, and realization of the Self have increased significantly. In general, the current people's needs for the better life show the following characteristics: (1) The diversity of needs. The needs of the people are characterized by multi-level and multi-aspect diversification. (2) The public content has enhanced. Social equality is an important symbol for the progress of social civilization. Equality is also one of the goals pursued tirelessly by humans. With the gradual improvement of people's material living standards, people's demands for democracy, the rule of law, fairness, justice, security, and environment are increasing.

The characteristics of people's needs in the new era, for the younger people, is the task and problem in the future, which requires the younger generation to break through themselves courageously, integrate themselves into the era and perceive the era. They cannot just feel satisfied by their life, happiness and achievement, nor waste life in the consumption and entertainment of technology and celebrity entertainment, party and games. The new mission in the new era requires the younger generation to be concerned about the society, the country and public affairs, armed with new ideas, and keep up with the general situation of the times and understand the responsibilities and mission. Secondly, the youth shall combine the development of individual career and national rejuvenation. Individual career is limited, however, closely related to national rejuvenation and the cause of the people, in this way, their individual stage would be vaster, and their career will be full of permanent charm and value. Xi Jinping said that "The youth is the future of the state, the hope of the nation, and the future and hope of the CPC." The national rejuvenation and happiness of the people require the younger people, especially educated youth. Young people are required to rely on national interests to inspire the vitality of innovation and creation, individual career and struggle should be placed on the great journey of national rejuvenation, and they must strive for practice, promote and undertake the mission of the times in order to maximize the value of life in serving the motherland and serve the people.

\section{The development of contemporary Chinese society and responsibility and mission of the youth}

$\mathrm{Xi}$ Jinping points out that development is the key to all problems. The solution of major contradiction of the society is the comprehensive progress and development of the society, which relies on the joint efforts of the people, especially the younger generation.

The fuller development is actually the overall development of mankind, which is a higher-level demand objective and a manifestation of social progress. At present, although China's social economy has developed a lot, as the 19th National Congress of the CPC that "Some outstanding problems of unbalanced development have not yet been solved. For example, the quality and benefits of development are still poor, and innovation capacity is not strong enough, the level of real economy needs to be improved, and there is a long way to go for ecological environmental protection". At present, the problem of insufficient social development in our country is relatively prominent, mainly including the quality and benefits, the innovation capability and environmental problems of the development.

(1) The quality and benefits of development. The speed of the development of China creates a Chinese miracle in modern history of the world. With the deepening of economic development, the quality and benefits of the development become prominent problem. The economic structure needs to be optimized further and the efficiency of resources use needs to be improved.

(2) The innovation capability in development. At present, the declining speed of economic development is related to the low economic development of the world, however, it is more important to solve the insufficient driving energy in further development, and the core of promoting 
the economic social development is to strengthen innovation capability to promote the further development of economic society.

(3) The environmental problems in development. On one hand, the high speed of the early stage of economic development benefits from policy advantage after reform and opening-up. On the other hand, our development is based on resources, and the use and deterioration of resources and environment is relatively serious in the development. In the future development, it is necessary for us to consider environment ecological problems to encourage people to obtain more sense of gain and happiness in the development.

The five development concepts of "innovation, coordination, green, openness, and sharing" proposed by the Fifth Plenary Session of the 18th Central Committee of the CPC are powerful ideological weapons for solving the problems of unbalanced development. The above problems in the development of the new era have put forward new requirements for contemporary youth.

(1) The young generation must work hard diligently. Faced with problems in the further development, the younger generation is required to set great aspiration and establish strong ideal and belief, to develop high-level, high-quality development in the economy and society with the development of capacity, and to make great contribution to the modernization development of socialism with Chinese characteristics and the construction of moderately prosperous society in an all-round way.

(2) The younger people should undertake new responsibility and mission. Innovation is the engine of a country's prosperity and the soul of a nation's progress, which has been proved in the history of human development and the progress of the country. And young people are the hope of a country. Youth have dreams and the country has a future. Young people are the most dynamic and creative group in Chinese society today and should be at the forefront of national development and innovation. The young people must have the daring spirit of daring to be the first and establish ambitions to inherit and surpass their predecessors. "To create youthful family, country, nation, humans, earth and the universe with the youth and to enjoy a permanently youthful life.” [5]

(3) The youth and ecological protection. Our era is a new era of ecological civilization, and a new era for the construction of a beautiful China. The young generation also has to shoulder the glorious and arduous mission of the times in protecting the environment, beautifying the ecology, and maintaining sustainable development. Young people are the "owners" of ecological civilization. The new era requires young people to establish a sense of ecological awareness for sustainable development, establish and strengthen the concept of environmental protection, together with young people around the world, consciously become the promoters and forces of ecological civilization construction, with more actions and fewer slogans, and consciously promote green development, cyclic development, and low-carbon development.

\section{The international development and responsibility and mission of the youth}

The development of China in the new era is not only based on its own development, but also a worldwide development. The 5th Plenary Session of the 18th CPC Central Committee considered China's development issues from a global perspective and proposed the concept of open development, which not only clearly indicated to the world that the "China's opening door will never be closed", but also clearly revealed the internal win-win logic that "The destiny of the Chinese economy is closely related to the destiny of the world”. China's opening up is not focused on its own development, but mutual benefit and win-win, aiming to create an inclusive human destiny community.

China's development is open and shared. The community of human destiny is a community of interests, a community of development, a community of civilization, and a community of cooperation, and we must establish the thinking of mutual benefit and win-win. Young people must have "a sense of mission" that is responsible for the people, history, and the world. In the context of globalization, it is necessary for the young people to have the vision of globalization, concern and understand the world, and be a compatible international citizen, at the same time, have a firm value orientation and a strong sense of morality. 
The global issue of development has granted contemporary youth new mission. Contemporary youth undertakers show the world the image of China and promote the new concept of peaceful development. The report of the 19th National Congress of the CPC put forward proposals that " to build a community of human destiny, and build a world with lasting peace, universal security, common prosperity, openness and inclusiveness, clean and beautiful." Chinese youth should consciously become the main force opposing hegemonism and power politics and become a powerful force with responsibility, ability, and confidence to advance human peace and development.

The new era also gives contemporary young people the task of shouldering the historical mission of cultural awareness, cultural heritage, and cultural transmission. Contemporary Chinese youth should "actively spread Chinese culture, tell Chinese stories, and speak out Chinese voice", create the most beautiful "Chinese name card" with the passion of youth, and promote the dream of China and the peoples of all countries to make joint contribution for the lofty cause of the peace and development of mankind. The new Chinese younger generation needs more cultural awareness and cultural confidence.

The young people today also shoulder the mission of contributing Chinese programs and Chinese wisdom to the world. At present, such global issues facing the world as population issues, environmental issues, resources issues, financial issues, political issues, cyber security issues, etc. diverse and varied. To meet the challenges of global issues, first of all, the young generation is required to profoundly understand and grasp the major global issues and trends. Chinese leaders with $\mathrm{Xi}$ Jinping as general secretary carried out top-level design for world development and provided Chinese programs, Chinese contributions, and Chinese wisdom, offering solutions, hope and "positive energy" to the world respectively ${ }^{[6]}(\mathrm{p} 6)$. The solution of global issues requires the joint and unremitting efforts of the people of the world, and requires the inheritance, succession, and struggle of the global young generation. The construction of the human destiny community and the realization of a "win-win and sharing" China program require the younger generation's peculiar diligence and vigilance in "Chinese kungfu" and the bottom-line thinking and communicative rationality ${ }^{[7]}(\mathrm{p} 14)$. Chinese youth should shoulder the historic mission of promoting world peace and prosperity, establishing a new international political and economic order and committing to the common progress and development of all mankind.

\section{The youth should continue with the past and open up the future in the changed and unchanged.}

The report of the 19th Congress of the CPC pointed out that the new era of socialism with Chinese characteristics is our contemporary historical position. The times are changing, and the main social contradiction is changing. However, the idea and belief that the youth serve the motherland, serve the society, and contribute their youth remains the same. The young people should move forward with the times, move ahead and continue to innovate.

\subsection{Keep pace with the times and work hard.}

Contemporary youth should profoundly understand the connotation of Xi Jinping new era of socialism with Chinese characteristics, understand the strategic needs and direction of development in the new era, consciously integrate individual careers, personal values, with the needs of the country and society, and create brilliant life while making contributions to the society. Keep both unchanged the basic national conditions and the basic orientation in mind, contemporary youth cannot be complacent, and continue to work hard while actively struggling. The youth cannot go beyond the times, instead, start from the development of reality and be bold to advance ahead of the times to be the endeavorers, pioneers, and devotees of the times.

\subsection{Keep lofty ambitions and fulfill dreams.}

The report of the 19th Congress of the CPC put forward that "The young people shall strengthen their ideal and belief, keep lofty ambitions, keep their feet on the ground, be brave enough to make 
the tide of the times, fulfill their youthful dreams in fulfilling the vivid practice of Chinese Dream, and create a bright life in the unremitting struggle for the people's interests!” The old saying goes that the establishment of "knowledge, deeds, and merit", which is the truth that knowledge, ethics, and career are mutually reinforced. Both ability and integrity are the consistent standards for young talents from the CPC and the goals pursued by contemporary youth. The contemporary Chinese youth should appreciate the times, keep up with the times, cherish their ambitions, strengthen their ideal and belief, work diligently and study hard, make innovations, carry forward the spirit of arduous struggle, and temper their noble character;

\subsection{Renew ideas and keep innovative.}

In the new era, new changes have taken place from the social environment to the country's strategic needs, and to social life. Correspondingly, the way people deal with problems should also change. Contemporary youth will have a healthier and better lifestyle and a living environment with richer connotation quality in the new era, and higher platform for life development and more life experiences.

\section{Conclusion}

$\mathrm{Xi}$ Jinping pointed out in the report of the 19th Congress of CPC that "The country will be prosperous and strong due to the youth. The younger generation has ideals, skills, and responsibility, and the country will have the future and the nation have hope.” The Chinese dream is historical, realistic and future. The Chinese dream of the great rejuvenation of the Chinese nation will eventually become a reality in the relay efforts of generations of young people. Faced with the new era and the major contradiction in the new era, young people in the new era must dare to undertake the historic responsibility entrusted by this era, strive for the realization of the two centenary goal and the Chinese dream of the great rejuvenation of the Chinese nation.

\section{Acknowledgements}

Fund project: 2017 shaanxi province teaching reform of colleges and universities research project. The phased result of life discourse system construction of classroom teaching of Basic Principle of Marxism.

\section{References}

[1] Xi Jinping. Determine the victory in the construction of moderately prosperous society in an all-round way, take the victory in the socialism with Chinese characteristics in the new era.-The report in the 19th Congress of $\mathrm{CPC}[\mathrm{R} / \mathrm{OL}]$

http://www.china.com.cn/cppcc/2017-10/18/content_41752399.htm

[2] Mao Zedong. The Volume 1 of Selected Works of Mao Zedong [C] Beijing: People's Publishing House, 1991.

[3] Xi Jinping. Speech of Xi Jinping in the investigation of China University of Political science and Law in May $4^{\text {th }}, 2017$.

[R/OL]. http://www.xatdj.com/news-22869-2.html

[4] Xi Jinping. Speech in the convention on the 95th anniversary of the founding of CPC [N]. People's Daily, July $2^{\text {rd }}$, 2016 (2).

[5] Li Dazhao. The Youth [J]. LA JEUNESSE, Vol 2, No. 1, September $1^{\text {st }}, 1916$.

[6] Chen Xiangyang. Chinese Strength and Wisdom Lead the Sustainable Development of the World [J]. Outlook Weekly, 2016 (39): 6-8.

[7] Fu Shouxiang. Chinese Wisdom and Civilization Consciousness of Human Destiny Community 
[J]. Seeker, 2017 (3): 14-19. 